\title{
Penerapan Pendekatan Pembelajaran Student Facilitator and Explaining dalam Upaya Meningkatkan Kemampuan Pemecahan Masalah Matematika Siswa
}

\author{
Titin Fatimah $^{\text {,a) }}$, Rahayu Kariadinata ${ }^{1}$, Yayu Nurhayati Rahayu ${ }^{1}$, dan \\ Wati Susilawati $^{1}$ \\ ${ }^{1}$ Prodi Pendidikan Matematika, UIN Sunan Gunung Djati Bandung, \\ J1. A.H. Nasution No. 105, Bandung 40614, Indonesia \\ ${ }^{a)}$ E-mail: pmtk@uinsgd.ac.id
}

\begin{abstract}
Abstrak. Penelitian ini bertujuan untuk memberikan gambaran proses pembelajaran matematika siswa, menelaah kemampuan pemecahan masalah matematika siswa pada tiap siklus, menelaah kemampuan pemecahan masalah matematika siswa setelah mengikuti seluruh siklus, menelaah sikap siswa kelas IX B SMP N 1 Cileunyi dalam kaitan kemampuan pemecahan masalah matematika siswa terhadap penerapan pendekatan pembelajaran Student Facilitator and Explaining pada pokok bahasan kerucut. Metode yang digunakan dalam penelitian ini adalah penelitian tindakan kelas (Classroom Action Research). penelitian tindakan kelas dilakukan melalui proses yang dinamis dan komplementari yang terdiri dari empat "momentum" esensial, yaitu: Penyusunan Rencana, Tindakan, Observasi dan Refleksi. Sampel yang digunakan dalam penelitian ini berjumlah 41 orang yang terdiri dari 19 orang laki-laki dan 22 orang perempuan. Instrumen yang digunakan untuk mengumpulkan data dalam penelitian ini terdiri dari lembar observasi untuk mengamati aktivitas guru dan siswa selama proses pembelajaran berlangsung, tes untuk mengukur kemampuan pemecahan masalah matematika, dan skala sikap untuk mengetahui sikap siswa. Hasil penelitian dapat disimpulkan bahwa penerapan pembelajaran Student Fasilitator and Explaining efektif untuk meningkatkan kemampuan pemecahan masalah matematik siswa. Disarankan dapat dimanfaatkan sebagai salah satu pertimbangan bagi guru bahwa pendekatan SFAE perlu dikembangkan karena dapat meningkatkan kemampuan pemecahan masalah.
\end{abstract}

Kata Kunci. Student Facilitator and Explaining, Pemecahan Masalah Matematika Siswa

\section{Pendahuluan}

Pendidikan merupakan sebuah proses dengan metode-metode tertentu sehingga orang memperoleh pengetahuan, pemahaman, dan cara bertingkah laku yang sesuai dengan kebutuhan (Syah, 2001). Dalam dunia pendidikan, matematika merupakan salah satu bidang studi yang menduduki peranan penting.

Matematika mampu memberikan
kemampuan bernalar yang logis, sistematik, kritis dan cermat, dimana akan sangat diperlukan dalam menghadapi masa depan yang selalu berubah.

Pada umumnya pembelajaran matematika di sekolah yang terjadi selama ini adalah guru lebih dominan di dalam kelas. Aktifitas guru jauh lebih besar dibandingkan aktifitas siswa. Komunikasinya cenderung masih satu arah. Kecenderungan pembelajaran yang demikian menyebabkan siswa tidak aktif, 
motivasi belajar menurun, dan tidak punya inisiatif baik dalam mengerjakan tugas, mengajukan pertanyaan maupun dalam mengungkapkan gagasan. Kenyataan demikian mengakibatkan siswa kurang mempunyai kesiapan apabila dihadapkan pada suatu permasalahan matematika (soal non rutin) yang menuntut siswa untuk melakukan suatu penyelesaian masalah yang kompleks.

Tuntutan dalam dunia pendidikan sudah banyak berubah, kita tidak bisa lagi mempertahankan paradigma lama mengenai pembelajaran yang bersifat konvensional. Teori penelitian dan pelaksanaan kegiatan belajar mengajar membuktikan bahwa guru sudah harus mengubah paradigma lama tersebut. Pendidikan perlu menyusun dan melaksanakan kegiatan belajar mengajar berdasarkan beberapa pemikiran, menurut (Lie, 2007) bahwa (1) Pengetahuan ditemukan, dibentuk dan dikembangkan oleh siswa; (2) Siswa membangun pengetahuan secara aktif; (3) Pengajar perlu mengembangkan kompetensi dan kemampuan siswa; (4) Pendidikan adalah interaksi pribadi di antara para siswa dan interaksi antara guru dan siswa.

Pembelajaran matematika di Indonesia haruslah diarahkan kepada kebutuhan masa depan yang sekiranya dapat mengembangkan kreativitas dan kemandirian siswa. Untuk keperluan itu matematika diajarkan dengan melatih para siswa untuk menyelesaikan masalah. Cara menyelesaikan masalah hendaknya membimbing siswa yang pada akhirnya siswa terlatih dan terkondisi untuk mampu belajar mandiri, sehingga diharapkan kebiasaan belajar aktif dapat terbina dengan baik dan siswa selalu bertanya terhadap informasi-informasi baru, tidak sekedar menerima informasi tanpa berfikir kritis.

Pemecahan masalah merupakan tujuan dalam pembelajaran matematika. Menurut (Susilawati, Perencanaan Pembelajaran Matematika, 2008) pemecahan masalah dalam matematika adalah aktivitas untuk menyelesaikan masalah yang cara penyelesaiannya belum mempunyai prinsip (aturan, rumus, dalil) tertentu yang segera dapat dipergunakan untuk menemukan jawaban terhadap masalah tersebut. Sedangkan menurut Polya (MKPBM, 2001), mendefinisikan pemecahan masalah sebagai usaha mencari jalan keluar dari kesulitan, mencapai tujuan yang tidak begitu saja dapat segera dicapai. 
Penerapan Pendekatan Pembelajaran Student Facilitator and Explaining dalam Upaya Meningkatkan Kemampuan Pemecahan Masalah Matematika Siswa

Menurut Polya (MKPBM, 2001), solusi soal pemecahan masalah memuat empat langkah penyelesaian, yaitu: memahami masalah (understanding the problem), merencanakan penyelesaian (devising a plan), melaksanakan rencana (carrying out the plan), dan memeriksa proses dan hasil (looking back).

Menurut pandangan Gagne berkaitan dengan kemampuan pemecahan masalah, bahwa "kemampuan berfikir tingkat tinggi banyak berkaitan dengan kemampuan memecahkan masalah". Pentingnya memiliki kemampuan pemecahan masalah matematika pada siswa diungkapkan Suhayati (Susilawati, Perencanaan Pembelajaran Matematika, 2008) berdasarkan pendapat Branca sebagai berikut: (1) Kemampuan penyelesaian masalah merupakan tujuan umum pengajaran matematika, bahkan sebagai jantungnya matematika; (2) Penyelesaian masalah meliputi metoda, prosedur dan strategi merupakan proses inti dan utama dalam kurikulum matematika; Penyelesaian matematika merupakan kemampuan dasar dalam belajar matematika.

kemampuan pemecahan masalah menjadi sangat penting dimiliki siswa dalam belajar matematika. Namun, permasalahan yang Jurnal Analisa Vol 1 No.2 Juni 2014 :73-86 timbul adalah pembelajaran matematika yang bagaimana yang dapat mengaktifkan siswa dan meningkatkan kemampuan pemecahan masalah matematika siswa. Salah satu upaya untuk menciptakan kemampuan pemecahan masalah matematika adalah dengan menerapkan pendekatan pembelajaran Student Facilitator and Explaining.

Penerapan pendekatan pembelajaran Student Facilitator and Explaining merupakan penerapan pembelajaran yang berpusat pada siswa. Tinggi rendahnya kadar aktivitas belajar siswa banyak dipengaruhi oleh strategi atau pendekatan mengajar yang digunakan. Richard Anderson (Hernawan, 2008) mengajukan dua pendekatan, yaitu pendekatan yang berorientasi pada guru. Pendekatan ini bersifat teacher centered. Pendekatan kedua lebih berorientasi pada siswa. Pendekatan ini bersifat student centered.

Dalam penerapan pembelajaran Student Facilitator and Explaining siswa menciptakan fasilitas/sumber belajarnya sendiri dan mempresentasikan ide atau pendapat mengenai konsep matematika pada siswa lainnya. Penerapan pembelajaran ini lebih mengedepankan kompetensi siswa, mendorong siswa memahami, memaknai dan memanfaatkan 
materi pelajaran matematika yang telah dipelajarinya. Penerapan pembelajaran student facilitator and explaining dapat membentuk kesiapan siswa dalam menggunakan kesempatan belajar untuk meraih manfaat, berupaya terlaksana, dan partisipatif dalam setiap kegiatan pembelajaran matematika.

Dalam penerapan pendekatan pembelajaran student facilitator and explaining siswa dituntut untuk menjadi subjek belajar dalam memecahkan masalah matematika sehingga kemampuan pemecahan masalah matematika siswa dapat meningkat dan kecerdasannya pun dapat berkembang.

Student Facilitator merupakan fase pembelajaran dengan mengutamakan kompetensi siswa dalam membuat bagan/peta konsep atau alat peraga sebagai sumber (fasilitas) belajar. Konsep merupakan kunci utama dalam pembelajaran.

Penelitian yang dilakukan mengambil sub materi kerucut. Pengambilan materi tersebut dikarenakan aplikasi pokok bahasan tersebut dalam kehidupan seharihari sangat luas, sehingga pokok bahasan ini sangat cocok apabila dipilih sebagai materi penunjang dalam rangka meningkatkan kemampuan pemecahan 76 masalah matematika siswa terutama yang berkaitan dengan kehidupan sehari-hari.

Berdasarkan uraian yang disampaikan, peneliti mengasumsikan bahwa penerapan pembelajaran Student Facilitator and Explaining akan mampu menjadikan siswa lebih aktif dalam menyampaikan gagasangagasan matematika, menjelaskan konsep matematika, aktif bertanya dan menjawab pertanyaan matematika, serta aktif dalam menyelesaikan suatu permasalahan matematika terutama yang berkaitan dengan soal non rutin (soal cerita).

Oleh karena itu, peneliti tertarik untuk melakukan penelitian dengan tujuan memberikan gambaran proses pembelajaran matematika siswa, menelaah kemampuan pemecahan masalah matematika siswa pada tiap siklus, menelaah kemampuan pemecahan masalah matematika siswa setelah mengikuti seluruh siklus, menelaah sikap siswa dalam kaitan kemampuan pemecahan masalah matematika siswa terhadap penerapan pendekatan pembelajaran Student Facilitator and Explaining.

Sehingga dapat dimanfaatkan untuk mengembangkan cara berfikir dan menjadikan motivasi bagi siswa agar menggunakan pengetahuan yang sudah ada dalam membentuk pengetahuan baru Jurnal Analisa Vol 1 No.2 Juni 2014 :73-86 
Penerapan Pendekatan Pembelajaran Student Facilitator and Explaining dalam Upaya Meningkatkan Kemampuan Pemecahan Masalah Matematika Siswa

dengan harapan siswa tidak lagi mengalami kesulitan ketika menghadapi permasalahan-permasalahan matematika terutama yang berhubungan dengan kehidupan sehari-har

\section{Metodologi Penelitian}

Penelitian dilakukan di SMP N 1 Cileunyi kelas IX. Pertimbangan peneliti memilih lokasi tersebut karena pembelajaran yang berlangsung di sekolah tersebut masih kurang melibatkan siswa untuk aktif dalam mengikuti pembelajaran matematika dan karena di lokasi tersebut belum pernah diterapkan pendekatan Student Facilitator and Explaining dalam pembelajaran matematika.

Kelas yang dijadikan subjek dalam penelitian ini yaitu kelas IX B. Dengan jumlah siswa 41 orang, dengan jumlah laki-laki 19 orang dan perempuan 22 orang. Jenis data yang digunakan untuk memecahkan permasalahan dalam penelitian ini adalah data kualitatif dan data kuantitatif.

Metode yang digunakan dalam penelitian ini adalah penelitian tindakan kelas (Classroom Action Research). Penelitian Tindakan Kelas (PTK) memiliki peranan yang sangat penting dan dapat meningkatkan mutu pembelajaran apabila diimplementasikan dengan baik dan benar.

Menurut Ebbut dan Hopkins penelitian tindakan kelas adalah kajian sistematik dari upaya perbaikan pelaksanaan praktik pendidikan oleh sekelompok guru dengan melakukan tindakan-tindakan dalam pembelajaran, berdasarkan refleksi mereka mengenai hasil dari tindakan-tindakan tersebut.

Lebih lanjut Kemmis dan Mc Taggart mengungkapkan bahwa penelitian tindakan kelas dilakukan melalui proses yang dinamis dan komplementari yang terdiri dari empat "momentum" esensial, yaitu: Penyusunan Rencana, Tindakan, Observasi dan Refleksi. Adapun alur penelitian tindakan kelas disajikan pada Gambar 1.

Instrumen yang digunakan untuk mengumpulkan data dalam penelitian ini adalah instrumen observasi digunakan untuk mengamati aktivitas guru dan siswa selama proses pembelajaran dengan menggunakan pendekatan pembelajaran Student Facilitator and Explaining yang sedang berlangsung, instrumen tes digunakan untuk mengukur kemampuan pemecahan masalah matematik siswa. 
Titin Fatimah, Rahayu Kariadinata, Yayu Nurhayati Rahayu, dan Wati Susilawati

Adapun tes yang digunakan dalam matematika dengan menerapkan penelitian ini berbentuk esay. Tes pada pendekatan pembelajaran Student penelitian ini terdiri dari tes formatif (quiz) tiap siklus dan tes akhir (post test), Facilitator and Explaining. Peneliti instrumen skala sikap digunakan untuk mengumpulkan data atau informasi tertulis menggunakan angket skala sikap model Likert, teknik penskoran dilakukan secara aposteriori.

tentang sikap siswa terhadap pembelajaran

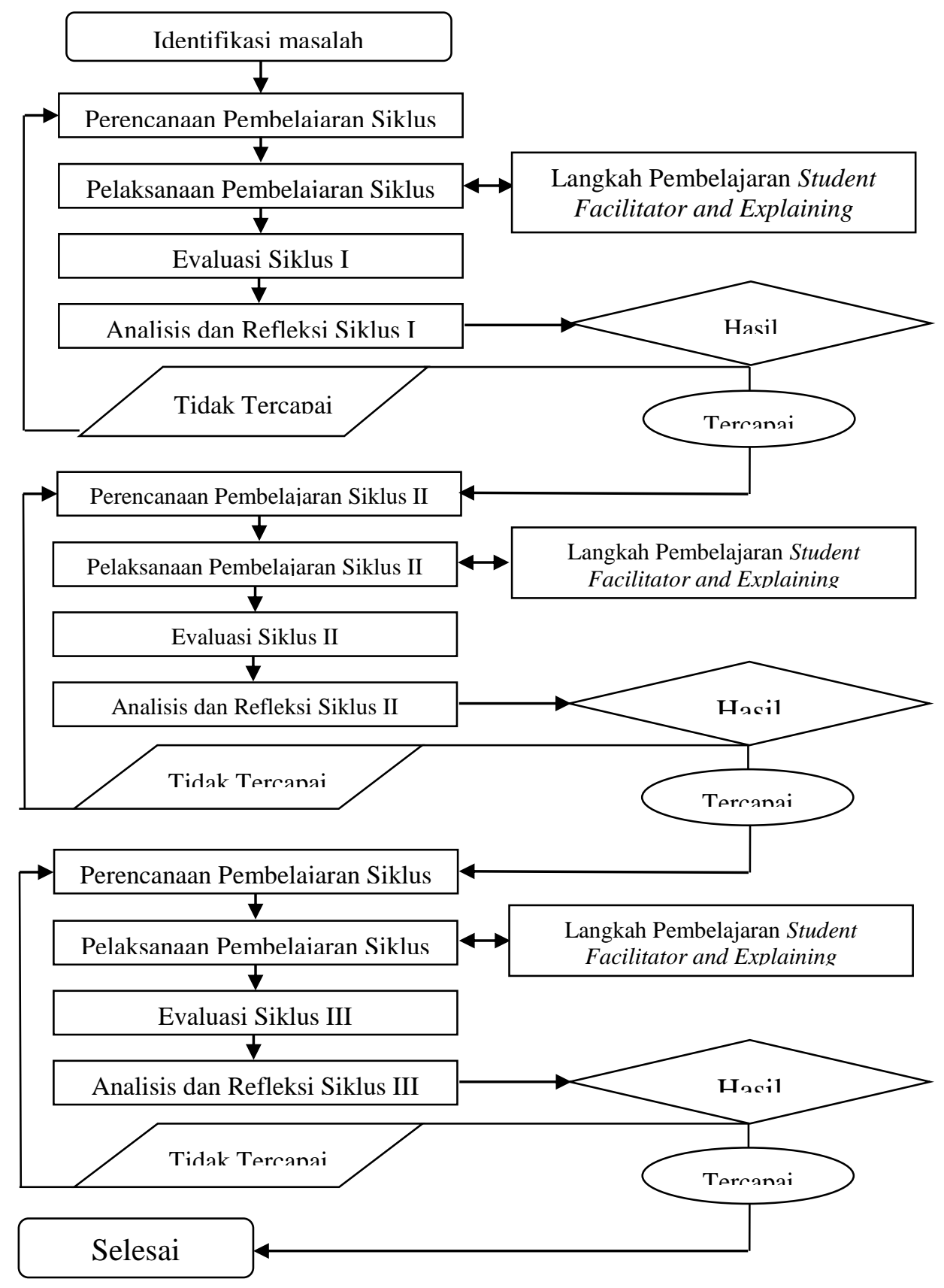

Gambar 1.

Alur Penelitian Tindakan Kelas 
Penerapan Pendekatan Pembelajaran Student Facilitator and Explaining dalam Upaya Meningkatkan Kemampuan Pemecahan Masalah Matematika Siswa

Adapun indikator sikap yang diamati yaitu: menunjukkan kesukaan siswa terhadap matematika, motivasi siswa terhadap pembelajaran matematika, tanggapan siswa terhadap pendekatan pembelajaran Student Facilitator and Explaining, menunjukkan minat siswa mengikuti proses pembelajaran dengan pendekatan Student Facilitator and Explaining, menunjukkan peran guru dalam pembelajaran dengan pendekatan Student Facilitator and Explaining, menunjukkan persetujuan siswa terhadap pendekatan pembelajaran Student Facilitator and Explaining dalam peningkatan kemampuan pemecahan masalah matematika, dan menunjukkan manfaat kemampuan pemecahan masalah matematika siswa. Teknik pengumpulan data disajikan pada Tabel 1 .

Tabel 1. Teknik Pengumpulan Data

\begin{tabular}{|c|c|c|c|c|}
\hline No & $\begin{array}{l}\text { Sumber } \\
\text { Data }\end{array}$ & Aspek & $\begin{array}{c}\text { Instrumen } \\
\text { yang } \\
\text { digunakan }\end{array}$ & $\begin{array}{c}\text { Teknik } \\
\text { Pengumpulan } \\
\text { Data } \\
\end{array}$ \\
\hline 1 & Siswa. & $\begin{array}{l}\text { Kemampuan Pemecahan masalah } \\
\text { matematika siswa. }\end{array}$ & Perangkat tes & $\begin{array}{l}\text { Tes pada siklus I, } \\
\text { II, III dan tes } \\
\text { akhir. }\end{array}$ \\
\hline 2 & $\begin{array}{l}\text { Guru dan } \\
\text { siswa. }\end{array}$ & Proses pembelajaran & $\begin{array}{c}\text { Lembar } \\
\text { observasi } \\
\text { aktivitas guru } \\
\text { dan siswa. }\end{array}$ & Observasi. \\
\hline 3 & Siswa. & $\begin{array}{l}\quad \text { Sikap siswa terhadap: } \\
\text { a. Pembelajaran matematika } \\
\text { b. Penerapan pembelajaran } \\
\text { menggunakan pendekatan } \\
\text { pembelajaran Student Facilitator } \\
\text { and Explaining } \\
\text { c. Manfaat penerapan pendekatan } \\
\text { pembelajaran Student Facilitator } \\
\text { and Explaining dalam } \\
\text { meningkatkan kemampuan } \\
\text { pemecahan masalah matematika }\end{array}$ & $\begin{array}{l}\text { Angket skala } \\
\text { sikap. }\end{array}$ & $\begin{array}{c}\text { Penyebaran } \\
\text { angket di kelas } \\
\text { setelah selesai tes } \\
\text { akhir. }\end{array}$ \\
\hline
\end{tabular}

\section{Hasil dan Pembahasan}

Berdasarkan penelitian yang telah Hasil observasi berdasarkan lembar dilakukan di SMPN 1 Cileunyi diperoleh observasi terhadap aktivitas siswa tiap hasil sebagai berikut: siklusnya dapat dilihat pada Tabel 2. 
Tabel 2. Aktivitas Siswa pada tiap Siklus

\begin{tabular}{|c|c|c|c|c|}
\hline No & Aspek yang diamati & $\begin{array}{c}\text { Persentase } \\
\text { Siklus I } \\
(\boldsymbol{\%})\end{array}$ & $\begin{array}{c}\text { Persentase } \\
\text { Siklus II } \\
(\boldsymbol{\%})\end{array}$ & $\begin{array}{c}\text { Presentase } \\
\text { Siklus III } \\
(\mathbf{\%})\end{array}$ \\
\hline 1 & Mengikuti pelajaran dengan baik & 80,3 & 86,5 & 88,8 \\
\hline 2 & $\begin{array}{c}\text { Berperan aktif dalam mengikuti kegiatan } \\
\text { pembelajaran/merespon apa yang dilakukan } \\
\text { guru }\end{array}$ & 67,8 & 80,4 & 90,7 \\
\hline 3 & Mengerjakan soal dengan baik & 71,1 & 81,1 & 85,6 \\
\hline 4 & Berbagi ide dengan siswa lain & 71,7 & 73 & 80,6 \\
\hline & Jumlah & 290.9 & 321 & 345,7 \\
\hline & Rata-rata aktivitas siswa & 72,7 & 80,3 & 86,4 \\
\hline
\end{tabular}

$$
\begin{aligned}
\text { Catatan }: \quad & 0 \% \leq \text { Tidak baik } \leq 50 \% \\
50 \% & <\text { Cukup } \leq 65 \% \\
65 \% & <\text { Baik } \leq 80 \% \\
80 \% & <\text { Amat baik } \leq 100 \%
\end{aligned}
$$

Dari Tabel 2. dapat dilihat bahwa pada siklus I siswa belum begitu optimal, ketidakoptimalan ini disebabkan mereka harus beradaptasi dengan pembelajaran yang dianggap baru bagi mereka, namun secara keseluruhan kegiatan pembelajaran berjalan sesuai yang diharapkan, aktivitas siswa termasuk kategori yang baik.

Pada siklus II siswa sudah optimal, ketidakoptimalan ini disebabkan mereka sudah bisa beradaptasi dengan pendekatan pembelajaran yang diterapkan. dengan kata lain secara keseluruhan kegiatan pembelajaran berjalan sesuai yang diharapkan, aktivitas siswa termasuk kategori yang amat baik.

Pada siklus III siswa sudah optimal, keoptimalan ini disebabkan mereka sudah tidak canggung lagi untuk berperan aktif dalam proses pembelajaran dan mengungkapkan ide. Pada siklus III ini aktivitas siswa termasuk kategori amat baik.

Berdasarkan hasil analisis observasi diperoleh bahwa perkembangan aktivitas tiap siswa mengalami peningkatan, hal ini dapat dilihat dari rata-rata presentase aktivitas siswa pada setiap pertemuan. Dari siklus I $(72,70 \%)$ ke siklus II $(80,30 \%)$ aktivitas siswa mengalami peningkatan 
Penerapan Pendekatan Pembelajaran Student Facilitator and Explaining dalam Upaya Meningkatkan Kemampuan Pemecahan Masalah Matematika Siswa

sebesar 7,60\%, kemudian dari siklus II $(80,30 \%)$ ke siklus III $(86,40 \%)$ mengalami peningkatan sebesar $6,10 \%$.

Kondisi ini menggambarkan bahwa siswa mampu mengikuti kegiatan proses pembelajaran Student Facilitator and Explaining yang diterapkan oleh guru. Secara keseluruhan rata-rata persentase aktivitas siswa pada setiap pembelajaran disajikan pada Tabel 3.

Tabel 3. Rata-rata Persentase Aktivitas Siswa Pada Tiap Siklus

\begin{tabular}{ccc}
\hline Siklus I & Siklus II & Siklus III \\
\hline $72,7 \%$ & $80,3 \%$ & $86,4 \%$ \\
\hline
\end{tabular}

Berdasarkan hasil analisis observasi aktivitas siswa mengikuti pembelajaran menggunakan pendekatan pembelajaran Student Facilitator and Explaining pada materi kerucut termasuk kategori baik, hal ini terlihat dari antusias siswa selama mengikuti pembelajaran Student
Facilitator and Explaining yang diterapkan oleh peneliti dan peningkatan aktivitas dari setiap siklus.

Untuk mengetahui kemampuan pemecahan masalah matematika siswa tiap siklusnya peneliti menggunakan perhitungan, yaitu: Ketuntasan belajar siswa secara klasikal, Kemampuan siswa tiap indikator pemecahan masalah matematika dan Daya serap klasikal yang kemudian dikonversikan ke dalam persentase kemampuan pemecahan matematika siswa.

Ketuntasan belajar yang dijadikan pijakan dalam penelitian ini sesuai Kriteria Ketuntasan Minimal (KKM) SMP N 1 Cileunyi, bahwa seseorang disebut telah tuntas belajar, jika sekurang-kurangnya dapat mengerjakan soal dengan benar sebanyak $85 \%$. Berdasarkan hasil perhitungan data tes formatif siswa pada setiap siklus diperoleh keterangan seperti terlihat pada Table 4 .

Tabel 4 Kemampuan Pemecahan Masalah Matematika Siswa pada Tiap Siklus

\begin{tabular}{|c|l|c|c|c|}
\hline No & \multicolumn{1}{|c|}{ Indikator Pemecahan Masalah } & $\begin{array}{c}\text { Persentase } \\
\text { Siklus I (\%) }\end{array}$ & $\begin{array}{c}\text { Persentase } \\
\text { Siklus II (\%) })\end{array}$ & $\begin{array}{c}\text { Persentase } \\
\text { Siklus III } \\
(\boldsymbol{\%})\end{array}$ \\
\hline 1 & Memahami Masalah & 100 & 100 & 100 \\
\hline 2 & Merencanakan penyelesaian & 89,5 & 100 & 87.5 \\
\hline 3 & Menyelesaikan masalah sesuai rencana & 78,9 & 77.5 & 81.7 \\
\hline 4 & Memeriksa Kembali Hasil & 50 & 47.8 & 55 \\
\hline Daya Serap Klasikal & $\mathbf{7 5}$ & $\mathbf{7 2 , 4}$ & $\mathbf{7 7 . 2 5}$ \\
\hline Ketuntasan Klasikal & $\mathbf{9 4 , 7}$ & $\mathbf{9 1 , 9}$ & $\mathbf{9 7 . 5}$ \\
\hline Rata-rata Kemampuan Pemecahan Matematik & $\mathbf{7 6 , 6}$ & $\mathbf{7 7 , 3}$ & $\mathbf{7 8 . 8}$ \\
\hline
\end{tabular}


Dari Tabel 4 diperoleh keterangan bahwa rata-rata presentase pada setiap siklus mengalami peningkatan, hal ini dapat dilihat dari rata-rata kemampuan Kondisi ini menggambarkan bahwa kemampuan pemecahan masalah matematika siswa mengalami peningkatan walaupun hanya sebesar $2,2 \%$ dan siswa mampu mengikuti proses pembelajaran yang diterapkan oleh guru. Secara keseluruhan rata-rata presentase kemampuan pemecahan masalah matematika siswa disajikan pada Tabel 5 dan Gambar 2.

Tabel 5. Rata-Rata Persentase

Kemampuan Pemecahan Masalah

Matematika Siswa Pada Setiap Siklus

\begin{tabular}{ccc}
\hline Siklus I & Siklus II & Siklus III \\
\hline $76,6 \%$ & $77,3 \%$ & $78,8 \%$ \\
\hline
\end{tabular}

pemecahan masalah matematika siswa pada setiap pertemuan. Dari siklus I $(76,6 \%)$ ke siklus II $(77,3 \%)$ Kemudian ke siklus III $(78,8 \%)$.

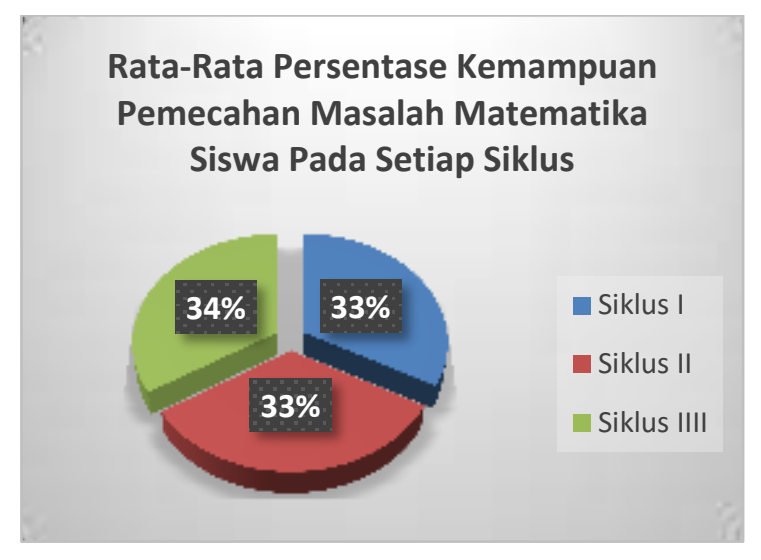

Gambar 2. Grafik Peningkatan

Kemampuan Pemecahan Masalah

Matematika Siswa Pada Setiap Siklus

Setelah seluruh siklus pembelajaran berakhir maka dilaksanakan post test untuk mengetahui kemampuan pemecahan masalah matematika siswa pada sub pokok bahasan kerucut setelah mengikuti pembelajaran dengan menggunakan pendekatan pembelajaran Student Facilitator and Explaining. Berdasarkan hasil perhitungan data tes akhir diperoleh keterangan sebagaimana tertera pada Tabel 6 dan Gambar 3.

Tabel 6. Kemampuan Pemecahan Masalah Matematika Siswa pada Akhir Seluruh Siklus

\begin{tabular}{|c|l|c|}
\hline No & \multicolumn{1}{|c|}{ Indikator Pemecahan Masalah } & Ketercapaian (\%) \\
\hline 1 & Memahami Masalah & 97.9 \\
\hline 2 & Merencanakan penyelesaian & 96 \\
\hline 3 & $\begin{array}{l}\text { Menyelesaikan masalah sesuai rencana (melakukan } \\
\text { perhitungan) }\end{array}$ & 90,7 \\
\hline
\end{tabular}


Penerapan Pendekatan Pembelajaran Student

Facilitator and Explaining dalam Upaya

Meningkatkan Kemampuan Pemecahan Masalah

Matematika Siswa

\begin{tabular}{|c|l|c|}
\hline 4 & Memeriksa Kembali Hasil & 74,3 \\
\hline Daya Serap Klasikal & 86,3 \\
\hline Ketuntasan Klasikal & 97,4 \\
\hline Rata-rata Kemampuan Pemecahan Matematik & 87,9 \\
\hline
\end{tabular}

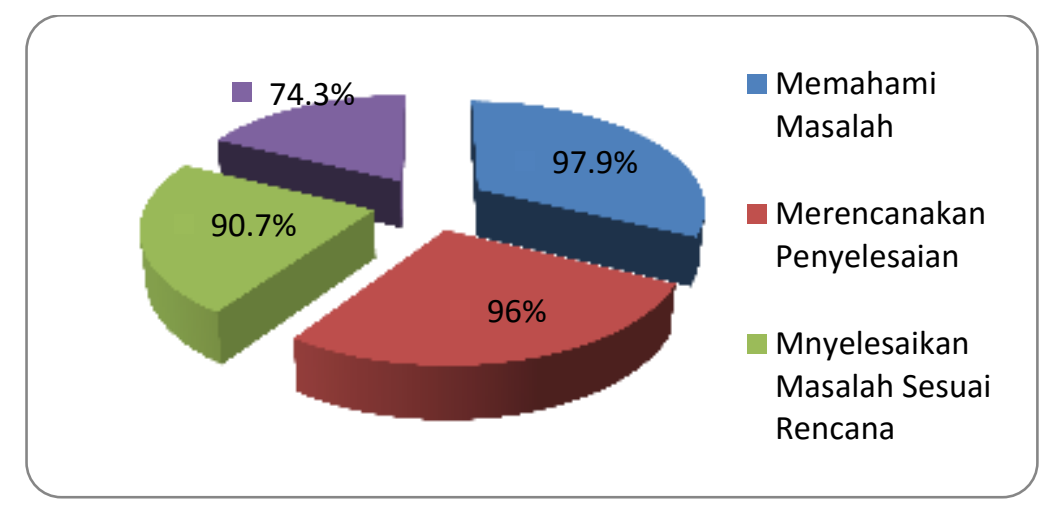

Gambar 3. Grafik Persentase Tiap Indikator Pemecahan Masalah

Matematik pada Akhir Seluruh Siklus

Adapun perkembangan kemampuan siklus 1, siklus 2, siklus 3 dan evaluasi pemecahan masalah matematika siswa akhir, sebagaimana disajikan pada Tabel 7 dapat dilihat dari ketercapaian hasil tes dan Gambar 4.

Tabel 7. Rata-rata Kemampuan Pemecahan Masalah Matematik

\begin{tabular}{|c|c|c|c|}
\hline No. & Evaluasi & $\begin{array}{c}\text { Rata-rata Persentase Kemampuan } \\
\text { Pemecahan Masalah Matematik } \\
\text { Siswa (\%) }\end{array}$ & Kriteria \\
\hline 1 & Tes Siklus I & $\mathbf{7 6 , 6}$ & Baik \\
\hline 2 & Tes Siklus II & $\mathbf{7 7 . 3}$ & Baik \\
\hline 3 & Tes Siklus III & $\mathbf{7 8 . 8}$ & Baik \\
\hline 4 & Tes Akhir & 87,9 & Baik \\
\hline
\end{tabular}

Dari Tabel 7 Dapat dilihat untuk matematik. Kemampuan pemecahan rata-rata persentase kemampuan masalah matematik siswa siklus I sebesar pemecahan masalah matematik siswa pada $76.6 \%$, siklus II sebesar $77.3 \%$, siklus III setiap siklusnya mengalami peningkatan. sebesar $78.8 \%$ dan akhir siklus $87.9 \%$. Hal ini menunjukkan bahwa siswa pada Untuk lebih jelasnya dapat dilihat pada setiap siklusnya mulai terbiasa gambar 3.25

mengerjakan soal-soal pemecahan masalah 


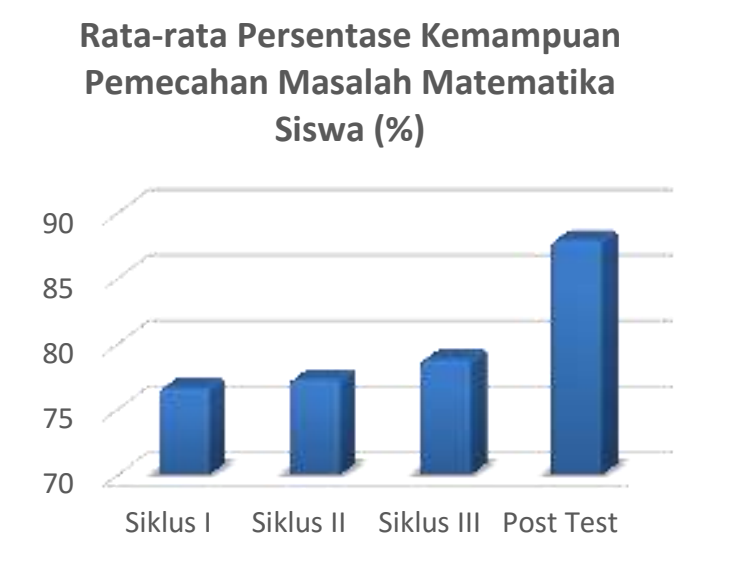

Pada Gambar 4 terlihat bahwa dari siklus I sampai post test, kemampuan pemecahan masalah matematika siswa terus mengalami peningkatan sampai hampir mencapai 90\%. Meskipun pada setiap siklus peningkatannya hanya sedikit, tetapi pada akhir seluruh siklus peningkatan mencapai puncaknya.

Berdasarkan hasil analisis data skala sikap diperoleh bahwa sikap siswa terhadap pembelajaran matematika melalui penerapan pendekatan pembelajaran Student Facilitator and Explaining cukup baik. Hal ini dapat dilihat dari rata-rata skor sikap siswa lebih besar dari pada skor sikap netral siswa, kondisi tersebut menunjukkan bahwa siswa memiliki sikap positif, baik terhadap pembelajaran matematika, terhadap pendekatan pembelajaran Student Facilitator and Explaining, maupun terhadap manfaat pendekatan pembelajaran Student

$\begin{array}{llr}\text { Gambar 4. } & \text { Grafik } & \text { Persentase } \\ \text { Perkembangan } & \text { Kemampuan } & \text { Pemecahan } \\ \text { Masalah } & \text { Matematik } & \text { Siswa }\end{array}$

Facilitator and Explaining dalam meningkatkan kemampuan pemecahan masalah matematika siswa.

\section{Simpulan dan Saran}

Berdasarkan hasil pembahasan yang telah diuraikan, maka dapat disimpulkan: (1) proses pembelajaran yang diperlihatkan melalui aktivitas siswa selama pembelajaran mengalami peningkatan pada tiap siklusnya. Hal ini dapat dilihat dari persentase rata-rata aktivitas siswa pada tiap siklus yang terus meningkat. Sedangkan aktivitas guru selama proses pembelajaran selalu berpijak pada tahaptahap pembelajaran yang telah direncanakan dan mengalami peningkatan pada tiap siklusnya. (2) Peningkatan kemampuan pemecahan masalah matematika siswa pada tiap siklus melalui pendekatan Student Facilitator and Explaining mengalami peningkatan pada Jurnal Analisa Vol 1 No.2 Juni 2014 :73-86 
Penerapan Pendekatan Pembelajaran Student Facilitator and Explaining dalam Upaya Meningkatkan Kemampuan Pemecahan Masalah Matematika Siswa

setiap siklusnya (3) Berdasarkan hasil analisis seluruh siklus diperoleh bahwa rata-rata persentase kemampuan pemahaman matematika siswa setelah diterapkan pendekatan Student Facilitator and Explaining menunjukkan pada kriteria baik dengan ketuntasan belajar lebih besar dari kriteria yang ditentukan. (4) Dari hasil analisis lembar skala sikap diperoleh bahwa sikap siswa terhadap pembelajaran matematika melalui penerapan pendekatan pembelajaran Student Facilitator and Explaining cukup baik. Hal ini dapat dilihat dari rata-rata skor sikap siswa lebih besar dari pada skor sikap netral siswa, kondisi tersebut menunjukkan bahwa siswa memiliki sikap positif, baik terhadap pembelajaran matematika, terhadap pendekatan pembelajaran Student Facilitator and Explaining, maupun terhadap manfaat pendekatan pembelajaran Student Facilitator and Explaining dalam meningkatkan kemampuan pemecahan masalah matematika siswa. Untuk itu guru diharapkan didalam pembelajaran matematika menerapkan pendekatan Student Facilitator and Explaining sebagai salah satu inovasi dalam dunia pendidikan. Serta dapat dijadikan motivator bagi siswa untuk tidak cepat merasa puas dengan pengetahuan yang telah mereka dapatkan, melainkan harus terus menggali Jurnal Analisa Vol 1 No.2 Juni 2014 :73-86 pengetahuan-pengetahuan baru yang dapat memudahkan dalam meningkatkan kemampuan pemecahan masalah-masalah matematika, terutama masalah matematika yang merupakan bentuk pengaplikasian dalam kehidupan sehari-hari.

\section{Daftar Pustaka}

Azwar. (2003). Penyusunan Skala Psikologi. Yogyakarta : Pustaka Pelajar.

Djumanta, Wahyudin. (2008). Belajar Matematika Aktif dan Menyenangkan untuk Kelas IX SMP. Jakarta : Pusat Perbukuan Departemen Pendidikan Nasional

Hernawan, Asep Herry. (2008). Pengembangan Kurikulum dan Pembelajaran. Jakarta: Universitas Terbuka.

Juanda, Rifahana Yoga (2009). Upaya Peningkatan Kemampuan Komunikasi Matematika Siswa Melalui Model Pembelajaran Assurance, Relevance, Interest, Assesment, Satisfaction (ARIAS). Skripsi UIN Bandung: Tidak Diterbitkan.

Karnawi. (2009). Penerapan Model Pembelajaran Kooperatif Tipe Jigsaw Terhadap Pemecahan Masalah Matematika Siswa. Skripsi UIN Bandung: Tidak diterbitkan.

Lie, Anita. 2007. Mempraktikkan Cooperatif Learning di Ruang-ruang Kelas. Jakarta: PT Gramedia

Musriah. (2009). Peningkatan Keaktifan Siswa Dalam Pembelajaran Matematika Melalui Metode Student Facilitator And Explaining. Tersedia : http://etd.eprints.ums.ac.id/4931/1/A4 10050236.pdf 
Titin Fatimah, Rahayu Kariadinata, Yayu Nurhayati Rahayu, dan Wati Susilawati

Avianti Agus, Nuniek. (2008), Mudah Belajar Matematika Kelas IX SMP/MTs. PT Karya Persada

Nurhayati, Yetti. (2006). Kemampuan Siswa dalam Pemecahan Masalah Matematika melalui Pola Pembelajaran Matematika Ala Jepang. Skripsi UIN Bandung: Tidak diterbitkan.

Nurul Aisyah, Ruri. 2009. Penerapan Pembelajaran Kooperatif dengan Strategi Conceptual Understanding Procedures (CUPs) dalam Upaya Meningkatkan Kemampuan Pemecahan Masalah Matematika Siswa. Skripsi UIN. Tidak diterbitkan

Promodyowati, Dian. (2005). Pengaruh Model Pembelajaran Kooperatif Tipe Student Teams Achievement Division (STAD) Terhadap Kemampuan Pemecahan Masalah Siswa pada Konsep Luas dan Volum Bangun Ruang. Skripsi UIN Bandung: Tidak diterbitkan.

Safitri, Sopy. (2009). Penerapan Peta Konsep dalam Upaya Meningkatkan Kemampuan Komunikasi Matematika Siswa. Skripsi UIN Bandung: Tidak diterbitkan.

Sari. (2002). Peran Peta Konsep dalam Evaluasi Hasil Belajar Siswa pada Konsep Materi dan Penggolongannya (Studi Deskriptif di Siswa Kelas 1.8 SMU PGII 1 Bandung)

Sihabudin. (2010). Upaya Meningkatkan Kemampuan Pemecahan Masalah Matematika Siswa Melalui Model Pembelajaran Brain Based Learning $(B B L)$. Skripsi UIN Bandung: Tidak diterbitkan.

Suherman, H. Erman, M.Pd. (2008). Model Belajar dan Pembelajaran Berorientasi Kompetensi Siswa. [on- line]. Tersedia

http://whandi.net/2008/10/e-

dukasi/kumpulan-makalah/model-

belajar-dan-pembelajaran-berorientasi-

kompetensi-siswa.html

Suherman, dan Sukjaya. (1990). Petunjuk Praktis untuk Melaksanakan Evaluasi Pendidikan Matematika. Bandung: Wijaya Kusumah.

Susilawati, Wati. (2008). Belajar dan Pembelajaran Matematika. Buku Diktat Kuliah di Lingkungan UIN Sunan Gunung Djati Bandung: Tidak Dipublikasikan.

Susilawati, Wati. (2008). Perencanaan Pembelajaran Matematika. Buku Diktat Kuliah di Lingkungan UIN Sunan Gunung Djati Bandung: Tidak Dipublikasikan.

Suyatno, (2008). Model-model Pembelajaran Inovatif untuk Digunakan Guru. [on-line]. Tersedia :http://garduguru. blogspot.com/2008_08_01_archive.ht $\mathrm{ml}$

Syah, Muhibbin. (2001). Psikologi Pendidikan dengan Pendekatan Baru. Bandung: PT. Rosda Karya.

TIM MKPBM Jurusan Pendidikan Matematika. (2001). Model Pembelajaran Matematika Kontemporer. Bandung: JICA-UPI. 